\title{
CESIS
}

Electronic Working Paper Series

Paper No. 141

\section{The Innovation and Productivity Effect of Foreign Take-Over of National Assets}

Börje Johansson ${ }^{*}$, Hans Lööf* and Bernd Ebersberger ${ }^{\star *}$

$\left({ }^{*} \mathrm{CESIS}\right.$ and $\mathrm{KTH},{ }^{* *} \mathrm{MCI}$ Management Center Innsbruck)

September 2008 


\title{
The innovation and productivity effect
}

\section{of foreign take-over of national assets}

\author{
Börje Johansson ${ }^{*}$, Hans Lööf ${ }^{\dagger}$ and Bernd Ebersberger ${ }^{*}$
}

\begin{abstract}
Over the past decades, there has been a dramatic increase in the foreign-ownership of firms in the four Nordic countries Denmark, Finland, Norway and Sweden. This increase has generated interest in the welfare effect of foreign take-over of national assets. In this paper we ask: how would a firm's behaviour and performance have been if a foreign owner had not acquired the firm? The analysis is based on a sample of 5186 firm-level observations in four Nordic countries, of which close to 30 percent are owned by foreign companies. Using an empirical approach that accounts for both selection bias and simultaneity bias, we establish some new findings regarding foreign ownership. First, no robust difference in the propensity to be innovative can be established. Second, among the group of innovative firms, foreign-owned multinationals are generally outperformed by domestic multinationals in R\&D and innovation engagement. Third, despite the fact that domestic multinationals are considerably more involved in national innovation systems than other firms, they are not producing more innovation per R\&D-dollar, controlling for firm size, human capital and industry. Finally, we find that foreign takeover of firms is neutral with respect to labour productivity, and hence that no evidence of welfare gain or welfare drain of foreign ownership can be established.
\end{abstract}

Keywords: Multinational enterprises, Take-Over, Corporate governance, Cross-country comparison, Spillovers, R\&D, Innovation, Productivity

JEL Classification: C31; D21, F23; G34; L22; O31; O33

\footnotetext{
* Börje Johansson, CESIS, Centre of Excellence for Science and Innovation Studies, The Royal Institute of Technology, Stockholm and JIBS, Jönköping International Business School, Email: borje.Johansson@ihh.hj.se

${ }^{\dagger}$ Hans Lööf, CESIS, Centre of Excellence for Science and Innovation Studies, The Royal Institute of Technology, Stockholm, Email: hans.loof@infra.kth.se

${ }^{*}$ Bernd Ebersberger, MCI Management center Innsbruck, Internationale Fachhochschulgesellschaft mbH Studiengang Wirtschaft \& Management for Professionals Universitätsstraße 15, 6020 Innsbruck/Austria, Email:bernd.ebersbeger@mci.
} 


\section{INTRODUCTION}

Foreign-owned firms are by definition multinational firms, and ownership in another country is a result of foreign direct investments, FDI, which can be divided into acquisitions and investment in new companies or units (Greenfield investments). In this study we will methodologically approximate foreign ownership by foreign take-over or acquisitions and ask: What would the firm's behaviour and performance have been if a foreign owner had not acquired the firm?

Since we cannot make such counterfactual observations, we are using two different categories of domestically owned companies as control groups. The possible differences between domestic and foreign-owned firms are reflected by observed gaps in (i) the propensity to innovate, (ii) $\mathrm{R} \& \mathrm{D}$ and other innovation expenditures, (iii) innovation output and finally (iv) labour productivity. If the ceteris paribus assumption is satisfied, a reasonable conclusion is that a superior performance indicates possible welfare gains from FDI, while inferior results in terms of innovation and productivity indicate the opposite.

The methodological approximation is motivated by existing literature, which suggests that foreign acquisitions by far exceed new establishments as a share of FDI investments. As an example U.S. data (Feliciano and Lipsey 2002) demonstrate that between 1988 and 1998, outlays for acquisitions accounted for $83 \%$ of outlays for acquisitions and new establishments. The Swedish Institute for Growth and Policy Studies (ITPS) presents similar figures. During the period 1996 and 2000, acquisitions accounted for 77\% of the establishment of foreign ownership in Sweden and an additional 6\% was as the result of mergers.

Over the last decades, FDI flows have increased dramatically (see, for example, Barrios et al 2004). Export from foreign affiliates of multinational corporations represent more than a third of total word trade. Between 1990 and 2001 production in FDI-firms (production in enterprises located outside the country of residence of the owners) increased from 6 percent to 11 per cent of world total output (Grossman et al 2003). 
The process of growing involvement of foreign firms in domestic economies raises concerns about the impact on the host country, and still there is no general agreement on the issue of welfare gain or welfare drain. Empirical regularities or stylized facts, which have emerged from a large number of comparison studies on domestic and foreign-owned firms, give some suggestions to the "gain or drain" discussion. First, there is robust evidence that within countries, foreign-owned firms almost always pay higher wages than domestically owned firms. Second, foreign-owned firms generally have higher productivity then local firms. Third, the evidence for knowledge spillovers from foreignowned firms to domestic firms is mixed. Fourth, the evidence for a general growth impact from foreign-owned multinationals on the host-country is mixed.

A great deal of the attention paid to the phenomenon of foreign direct investments is focused on efficiency comparisons between foreign-owned and domestically owned firms, frequently in terms of productivity. The underlying assumption is mainly that productivity differences indicate a technological gap. Some work in this research area, following Findlay 1978, argues that a superior performance of foreign-owned firms creates a potential for technology transfer to the domestic firms. Others support the hypothesis that the lower the technological gap between domestic and foreign firms, the higher the potential benefits in terms of technology transfer to domestic firms (Cantwell, 1989).

The literature suggests some alternative explanations for the differences in performance between domestic and foreign-owned firms. Some studies suggest that only firms with superior technology or superior productivity are candidates for acquisitions or mergers. Other studies find that FDI investment is oriented toward high productivity sectors. A third finding is that acquisitions and mergers have a positive impact on efficiency of firms per se. Finally, if FDI can be conceived as a strategy to exploit technological advantages created within home countries a higher productivity should be expected due to scale economies and other competitive advantages. 
This paper adds to the growing FDI literature in three different aspects. First, it examines not just productivity differences between foreign-owned and domestically owned firms, but also differences in the efficiency with which the two categories of firms can utilize internal and external knowledge. Although there is a vast literature on the importance of FDI and foreign-owned firms, much of it has focused on the productivity issue. The effects of foreign-owned firms on the intensity of $R \& D$ and other innovation activities in the host country have been less scrutinized. Second, in order to include corporate governance in the analysis, we separate the foreign-owned firms into three categories of corporate style (Nordic, Anglo-Saxon and Rest of the world), and we divide the domestically-owned firms into two types of corporate structure (multinationals and uninationals, where the latter belong to a group with only domestic affiliates). Third, the study is an attempt to exploit the internationally harmonized Community Innovation Survey (CIS) data in order to compare the importance of foreign ownership in various countries, using uniform econometric frameworks. The authors address this issue from a large sample of 5186 firm-level observations across the four Nordic countries, Denmark, Finland, Norway and Sweden. The proportion of foreign-owned firms varies from $23 \%$ in Finland to $32 \%$ in Sweden. The average for the four countries is $28 \%$.

The remaining part of this paper is organized as follows. Section 2 discusses the embeddedness of multinational firms in national innovation systems of home and host countries. It also addresses the issue of technology and productivity gaps. Section 3 presents the data. Section 4 introduces the methodological approach. Section 5 describes the results, and Section 6 provides some conclusions.

\section{PREVIOUS RESEARCH}

The increasing globalization of corporate ownership has generated a surge in the interest in factors causing foreign direct investment (FDI) and the effect of foreign ownership on productivity, growth and welfare.

In the theoretical literature there are two broad classes of explanations of the sources and directions of the direct investment inflow. One explanation is that foreign-owned firms

$$
-5 \text { - }
$$


wish to gain access to location advantages of the host country, based on the host country endowments or the host country's technological skills, i.e., skills that are specific to the host country in general or to specific locations in the home country. In that case, we would expect to find investments to be attracted to industries in which the host country has some comparative advantage in trade.

The second explanation is that foreign-owned firms have built up firm-specific advantages in their countries, based on their home countries' current or past comparative advantages, and wish to exploit these in the host country, where established firms have lost or lack these skills. In that case we would expect to find that investments flow to industries with comparative disadvantages in the host country and originate from firms in industries in which their own home country has comparative advantages in trade.

Investigating determinants to foreign direct investments Helpman et al (2003) suggests that low-productivity firms serve only the domestic market while high-productivity firms also serve foreign markets. Among the high-productivity firms, the relatively less productive firms are closely associated with export while the relatively more productive firms have a large propensity to be engaged in foreign direct investment. Intuitively, we would therefore expect that FDI contributes to increased productivity is a host country.

The effect of FDI can be captured at different levels of economic aggregation. At the micro level, one branch of the literature compares the contributions to productivity between foreign and domestically owned firms. There is robust evidence in the literature that foreign-owned firms generally have higher productivity and pay higher wages than domestically owned firms. In contrast to broad agreements in the literature on productivity differences between foreign-owned firms and domestically owned firms, the attempts to explain the superiority of foreign-owned firms are less unanimous.

Doms and Bradford Jensen (1998), stress the importance of the particular strategy behind an FDI-investment: If foreign companies can overcome the cost of entering a foreign market, this might signal that these companies have specific advantages, such as

$$
-6-
$$


superior product design, greater production efficiency, and advanced marketing skill, relative to their domestically competitors. As a result, we would expect foreign firms to outperform domestically owned firms. Moreover, if the hypothesis that FDI is a strategy to exploit idiosyncratic advantages of the firm is correct, a higher productivity due to scale economies or other competitive advantages should be expected. But if the strategy of foreign firms is be to keep most of their high value-added activities close to their headquarters and outsource primarily their lower value-added activities, FDI will not necessarily lead to increased productivity.

Another line of arguments suggests that only firms with superior technology or superior productivity are candidates for acquisitions or mergers and that FDI investments are oriented towards sectors with high productivity. Without controlling for the historical background of the foreign-owned firm or industry classification, the productivity contribution by FDI would therefore be overestimated.

An empirical study by Harris and Robinson (2002) on what kind of companies foreign firms choose to acquire, does indeed suggest that foreign-owned firms selected plants with a relatively high productivity. Moreover, Conyon et al (1999) find that the acquisition of UK firms by foreigners leads to increases in their productivity. At variance with these results, investigating foreign ownership in the Swedish manufacturing sector between 1990 and 2000, Lundberg and Karpaty (2004) rejected the hypothesis that foreign-owned companies had a relatively higher productivity before the takeover.

A large fraction of the comparison studies are based on cross-sectional data and an important methodological issue is the presence of substantial heterogeneity across establishments within and between industries. Does the observed data contain enough with information for a proper control of idiosyncratic differences?

An early and illustrative example of the importance of appropriate control variables is Globerman, Ries and Vertinsky (1994) who in a first step find that foreign owned affiliate plants are more productive than Canadian-owned plants. In a second step, however, they include additional firm characteristics such as size, capital intensity, share 
of nonproduction workers and share of male workers. As a result the difference between the two categories of firms disappears.

The seminal paper by Doms and Bradford Jensen (1998) shows that it is not enough to control for traditional firm or plant characteristics. They suggest that the domestically owned plants should be separated into those belonging to (i) multinationals and (ii) domestic-oriented firms. As a group, domestically owned plants are less productive and pay less wages than foreign-owned plants even when controlling for four-digit industry, age, size and state. After a proper control for corporate ownership structure, however, the study found that both domestically owned and foreign-owned plants of multinational companies are more productive and pay higher wages than domestically oriented firms. Similar findings are presented by Pfaffermayr and Bellak (2002).

Partly following Dosi (1988), Porter (1990), Lundvall (1992) and Nelson (1992), one branch of FDI studies discusses the relationship between foreign-owned companies, national innovation systems, geographical proximity, industrial clusters and global networks. See for example Jaffe et al (1993), Audretsch and Feldman (1996), Kuemmerle (1999), Pavitt and Patel (1999) and Cantwell and Janne (1999). Some recent studies within this strand have analyzed the importance of the innovation systems in the host country for the performance of subsidiary business. Furu (1999), for instance, suggests that the general competitiveness of foreign-owned firms requires two things: First, the subsidiary has to establish business relationship with local counterparts as well as suppliers, competitors, customers, government agencies, in order to be able to absorb meaningful knowledge from the local competitive environment. Second, investment in $R \& D$ is needed to support the development of new competence and learning. The results presented by Furu confirm previous finding by Andersson (1997) that the performance of foreign-owned firms is largely dependent on its embeddedness in the network of local firms, e.g., local customers, suppliers, research institutes, and competitors.

The evidence for knowledge spillovers from foreign-owned firms to domestic firms is mixed in the literature. Foreign-owned firms can also substitute local suppliers with 
foreign ones, disrupting existing linkages (Lall 1979), and monopolize markets and draw demand away from domestic firms, causing them to cut production and reduce their efficiency (Aitken and Harrison 1999).

There is a small but growing empirical literature on foreign ownership and innovation relying on the same type of Community Innovation System (CIS) data as the present paper. A common research topic in these studies is the innovativeness of foreign-owned firms versus domestically owned firms. Using a dataset of 1,115 observations from CIS 2, Balcet and Evangelista (2004) show that foreign- owned firms were more innovative than domestic firms in Italy during the period 1994-1996. The authors explain this greater innovativeness of foreign-owned firms by their larger concentration in science-based sectors and by their larger size compared to domestic firms.

Frenz and Ietto-Gillies (2004) used a data set from the U.K. containing 679 observations from CIS 2 and CIS 3 to test the hypothesis that multinationality, per se, affects the propensity to innovate. Comparing domestic and foreign-owned firms belonging to a multinational company with firms belonging to a uninational company, they find that those CIS firms that belong to a multinational corporation are more likely to engage in innovation activities and that this engagement is persistent rather than occasional.

\section{DATA AND DESCRIPTIVE STATISTICS}

\subsection{Data}

The data used in this study was obtained from the internationally harmonized Community Innovation Survey III conducted by statistical agencies in Finland, Iceland, Norway and Sweden, and from a research institute in Denmark in 2001. It covers the years 1998 to 2000. In Norway the survey is compulsory which explains the large number of observations. In the other four countries the response rate was about 50 percent. The focus is on both manufacturing and service firms. As this analysis endeavors to establish the difference between "similar" foreign-owned and domestically owned firms, we constrained the set of firms in our sample to those firms that belonged to a corporate group. 
In order to include corporate governance in the analysis, we have separated the firms into five different groups. The first consists of firms belonging to a set with only domestic affiliates. These firms are labelled uninationals. The second group is domestic multinationals. The foreign firms are classified into three: Nordic, Anglo-Saxon and other multinationals. Based on the literature on corporate governance styles, we suspect that the home country of a corporate group can have a distinct influence the innovation activities of the firms. Hence, we include information about the home country of the corporate group in the analysis. Ex ante, we build country groups that are supposed to yield similar corporate governance styles, or that are of particular interest in the analysis. All other home countries in the sample are grouped into the category European and others, where European countries clearly dominate in number. ${ }^{\S}$

Community innovation survey data is increasingly being used as a key data source in the study of innovation at the firm level in Europe. Data based on the CIS questionnaire is not only available for the EU member states. Norway and Iceland also participate in the CIS initiative.* CIS surveys follow the 'subject-oriented' approach because they ask individual firms directly whether they were able to produce an innovation. The CIS is based on previous experience with innovation surveys, including the Yale survey and the SPRU innovation database (Klevorick et al, 1995; Pavitt, Robson and Townsend, 1987). Compared to the R\&D and patent data, innovation output indicators in the CIS have the advantage of measuring innovation directly (Kleinknecht et al 2002). The new indicators in the CIS capture the market introduction of new products and services and their relative importance for the innovators' sales. In addition, it contains information about the innovation process and in particular it contains information on innovation collaboration and knowledge sources.

\footnotetext{
${ }^{\S}$ It should be noted that we are aware of the fact that our method of defining the home-country of a firm after the location of its headquarter is somewhat arbitrary. However, the CIS-questionnaire gives no alternative options.

** Although Iceland is a Nordic country, and conducted an innovation survey in 2001, Iceland will not be included in the analysis. The results from a recent report by Ebersberger and Lööf, however, suggest that the involvement of foreign companies in the Icelandic economy reflects the findings for the other Nordic countries, see http://www.step.no/foton/reports/foton3.pdf
} 


\subsection{Descriptive statistics}

Table1: Sample size and the distribution of ownership

\begin{tabular}{|l|ccc|c|c|c|}
\hline & $\begin{array}{c}\text { Domestic } \\
\text { uninational }\end{array}$ & $\begin{array}{c}\text { Domestic } \\
\text { multinational }\end{array}$ & $\begin{array}{c}\text { Foreign } \\
\text { multinational }\end{array}$ & Total & $\begin{array}{c}\text { Foreign, } \\
\text { Fraction }\end{array}$ & $\begin{array}{c}\text { Innovative, } \\
\text { fraction }\end{array}$ \\
\hline Denmark & 574 & 47 & 223 & 844 & 26.4 & 50.8 \\
Finland & 541 & 93 & 184 & 818 & 22.5 & 63.0 \\
Norway & 1,556 & 55 & 685 & 2327 & 29.8 & 48.1 \\
Sweden & 752 & 62 & 383 & 1197 & 32.0 & 58.0 \\
\hline \multicolumn{1}{|c|}{ Total } & 3,423 & 257 & 1475 & 5,186 & 28.6 & 55.0 \\
\hline
\end{tabular}

The distribution of the sample and ownership distribution is described in Table 1. The four countries are all small economies with a large dependence on the international economy in terms of import and export, and they have an extensive presence of foreignowned firms. In total the data consists of 5,186 observations, of which 3,423 are uninational firms (firms belonging to a group with only domestic affiliates), 532 Nordic multinationals, 329 Anglo-Saxon multinationals, and 645 are other multinationals (dominated heavily by firms from Continental Europe). The proportion of foreign-owned firms ranges from $22.5 \%$ in Finland up to $32.0 \%$ in Sweden. The average for the Nordic counties is $28.6 \%$.

Table 2: Firm size distribution (employment)

\begin{tabular}{|c|c|c|c|c|c|c|}
\hline & \multicolumn{2}{|c|}{$\begin{array}{l}\text { Domestic } \\
\text { uninational }\end{array}$} & \multicolumn{2}{|c|}{$\begin{array}{c}\text { Domestic } \\
\text { multinational }\end{array}$} & \multicolumn{2}{|c|}{$\begin{array}{c}\text { Foreign } \\
\text { multinational }\end{array}$} \\
\hline & Mean & Median & Mean & Median & Mean & Median \\
\hline Denmark & 292 & 62 & 1975 & 600 & 210 & 83 \\
\hline Finland & 316 & 85 & 1835 & 407 & 180 & 89 \\
\hline Norway & 150 & 61 & 406 & 133 & 222 & 82 \\
\hline Sweden & 276 & 50 & 1277 & 355 & 348 & 105 \\
\hline Average & 259 & 65 & 1373 & 374 & 240 & 90 \\
\hline
\end{tabular}

A prominent feature in all Nordic countries, shown in Table 2, is that the domestic multinational firms are significantly larger than the domestic uninational firms and foreign- owned firms. Domestic multinational firms are 4-5 times larger than the firms in the two other groups.

Table 3: Firms' most significant market (Percentage of firms). 


\begin{tabular}{|l|ccc|ccc|ccc|}
\hline & \multicolumn{3}{|c|}{$\begin{array}{c}\text { Domestic } \\
\text { uninational }\end{array}$} & \multicolumn{3}{c|}{$\begin{array}{c}\text { Domestic } \\
\text { multinational }\end{array}$} & \multicolumn{3}{c|}{$\begin{array}{c}\text { Foreign } \\
\text { multinational }\end{array}$} \\
\hline & Local & National & Global & Local & National & Global & Local & National & Global \\
\hline Denmark & 21.1 & 43.4 & 35.5 & 10.6 & 31.9 & 57.5 & 12.6 & 52.9 & 34.5 \\
Finland & 25.4 & 47.9 & 26.6 & 1.1 & 21.5 & 77.4 & 3.8 & 53.3 & 42.9 \\
Norway & 39.4 & 40.4 & 20.2 & 5.5 & 23.6 & 70.9 & 28.3 & 47.0 & 24.7 \\
Sweden & 27.4 & 42.3 & 30.3 & 6.5 & 24.2 & 69.4 & 8.9 & 41.5 & 49.6 \\
\hline
\end{tabular}

Table 3 indicates that the most significant market for uninational firms is the domestic market, while multinationals focus on the global market. Interestingly, foreign-owned firms strongly focus on the national markets, whereas their focus on the local markets is considerably lower that of the domestic uninationals.

Table 4 shows firm's characteristics for the five different categories of firms investigated in the study. Looking firstly at Sales reported in the four left columns in Panels A-D, the largest average figures are found among domestic multinationals, in all Nordic countries, and the smallest among domestic uninationals. Comparing the aggregates of domestically owned and foreign-owned firms, respectively, the table shows only minor differences in Denmark and Finland, whereas the average foreign firm in Norway and Sweden outperforms the average domestic firm. Column 2 in Table 4 depicts average Labour productivity. In the study we have used sales per employee as our productivity measure. Here we see that the average value for foreign-owned firms in Denmark, Finland and Sweden is higher than that of both multinational and uninational domestic firms. In Norway, Nordic multinationals and Anglo-Saxon multinationals have higher labour productivity than domestic firms, even though continental European firms are less productive than Norwegian multinationals. Column 3 reports that domestically owned MNEs are more Export intensive than foreign MNEs. Domestic uninationals have considerable less expert per employee than other firms. The descriptive statistics on Gross investment and Human capital shows a robust pattern in Norway, Finland and Sweden: Domestic multinationals have most tangible capital and intangible capital than followed by foreign owned firms. In Denmark the foreign firms are slightly more capital intensive (tangible and intangible as well) than Danish MNEs. In all Nordic counties the 
uninationals are distinguished by having less physical capital per employee and less fraction of employees with a university education.

Table 4: Firms characteristics"

Panel A. Denmark

\begin{tabular}{|l|ccccc|}
\hline & Sales & $\begin{array}{c}\text { Labour } \\
\text { Product. }\end{array}$ & Export & Gross investment & Human capital \\
\hline Domestic UNI & 9.89 & 5.18 & 1.03 & 0.57 & 0.08 \\
Domestic MNE & 11.24 & 4.97 & 1.77 & 0.72 & 0.12 \\
Foreign MNE & 9.98 & 5.27 & 1.63 & 0.78 & 0.14 \\
\hline - Nordic & 9.96 & 5.33 & 1.51 & 0.78 & 0.11 \\
- Anglo-Saxon & 9.87 & 5.03 & 1.97 & 0.81 & 0.19 \\
- Rest of world & 10.06 & 5.38 & 1.54 & 0.77 & 0.14 \\
\hline
\end{tabular}

Panel B. Finland

\begin{tabular}{|l|ccccc|}
\hline & Sales & $\begin{array}{l}\text { Labour } \\
\text { Product. }\end{array}$ & Export & Gross investment & Human capital \\
\hline Domestic UNI & 9.35 & 4.84 & 2.27 & 1.52 & 0.33 \\
Domestic MNE & 11.30 & 5.24 & 4.06 & 1.98 & 0.43 \\
Foreign MNE & 9.69 & 5.26 & 3.92 & 1.28 & 0.38 \\
\hline-- Nordic & 9.45 & 5.12 & 3.05 & 1.11 & 0.35 \\
- Anglo-Saxon & 10.06 & 5.49 & 3.97 & 1.75 & 0.40 \\
- Rest of world & 9.64 & 5.24 & 2.94 & 1.03 & 0.40 \\
\hline
\end{tabular}

Panel C. Norway

\begin{tabular}{|l|ccccc|}
\hline & Sales & $\begin{array}{l}\text { Labour } \\
\text { Product. }\end{array}$ & Export & Gross investment & Human capital \\
\hline Domestic UNI & 11.39 & 7.22 & 2.56 & 3.04 & 0.24 \\
Domestic MNE & 12.35 & 7.41 & 6.13 & 3.72 & 0.42 \\
Foreign MNE & 11.78 & 7.33 & 3.33 & 3.11 & 0.31 \\
\hline- - Nordic & 11.82 & 7.43 & 2.81 & 2.99 & 0.29 \\
- Anglo-Saxon & 11.90 & 7.50 & 4.19 & 3.30 & 0.40 \\
- Rest of world & 11.71 & 7.22 & 3.39 & 3.12 & 0.28 \\
\hline
\end{tabular}

Panel D. Sweden

\begin{tabular}{|l|ccccc|}
\hline & Sales & $\begin{array}{c}\text { Labour } \\
\text { Product. }\end{array}$ & Export & Gross investment & Human capital \\
\hline Domestic UNI & 11.36 & 5.00 & 1.87 & 3.49 & 0.17 \\
Domestic MNE & 13.18 & 5.17 & 3.61 & 3.78 & 0.21 \\
Foreign MNE & 12.17 & 5.30 & 3.21 & 3.59 & 0.18 \\
\hline-- - Nordic & 12.09 & 5.32 & 3.06 & 3.46 & 0.14 \\
- Anglo-Saxon & 12.31 & 5.36 & 3.76 & 3.75 & 0.21 \\
- Rest of world & 12.14 & 5.25 & 2.96 & 3.60 & 0.20 \\
\hline
\end{tabular}


I/, Note: Sales, labour productivity, export and gross investment are all expressed in per capita terms and in logs. The currency unit is Euro in Denmark, Finland and Sweden and Norske Kroner for Norway. Human capital is expressed as the fraction of the work force with higher education.

Table 5 describes the innovation input and the innovation output of innovating firms. Both are expressed here as a fraction of sales. The average uninational firm and the average Anglo-Saxon, European and other multinational firms invest about seven to eight percent of sales income in innovation activities including $R \& D$. The innovation input is considerably larger in the average domestic multinational firm, whereas the foreignowned firms and the domestic uninational firms are comparable in terms of innovation input. Also for innovation output measured by the fraction of sales generated from new products and services, we find that domestic multinationals reveal a higher intensity than both the domestic uninationals and the foreign-owned firms.

Table 5: Innovation input and Innovation sales, as a fraction of sales. Standard deviation in parentheses.

\begin{tabular}{|l|lc|lc|cc|}
\hline & \multicolumn{2}{|c|}{$\begin{array}{c}\text { Domestic } \\
\text { uninational }\end{array}$} & \multicolumn{2}{c|}{$\begin{array}{c}\text { Domestic } \\
\text { multinational }\end{array}$} & \multicolumn{2}{c|}{$\begin{array}{c}\text { Foreign } \\
\text { multinational }\end{array}$} \\
\hline & $\begin{array}{c}\text { Innovation } \\
\text { input }\end{array}$ & $\begin{array}{c}\text { Innovation } \\
\text { output }\end{array}$ & $\begin{array}{c}\text { Innovation } \\
\text { input }\end{array}$ & $\begin{array}{c}\text { Innovation } \\
\text { output }\end{array}$ & $\begin{array}{c}\text { Innovation } \\
\text { input }\end{array}$ & $\begin{array}{c}\text { Innovation } \\
\text { output }\end{array}$ \\
\hline Denmark & $8.6(21.3)$ & $24.8(27.0)$ & $14.1(24.9)$ & $27.0(25.8)$ & $8.8(21.0)$ & $25.7(24.0)$ \\
Finland & $6.1(14.9)$ & $16.2(23.6)$ & $9.1(15.7)$ & $25.6(27.5)$ & $6.9(15.6)$ & $18.4(23.6)$ \\
Norway & $7.1(16.8)$ & $20.5(24.6)$ & $16.7(26.3)$ & $30.8(28.5)$ & $8.8(19.7)$ & $22.6(26.3)$ \\
Sweden & $8.4(19.4)$ & $15.2(24.2)$ & $15.0(25.7)$ & $23.9(28.0)$ & $6.2(14.1)$ & $18.8(24.4)$ \\
\hline
\end{tabular}

As we discussed in section 2, recent literature emphasizes the importance of innovation systems for the performance of individual firms. Table 6 reports the percentage of companies, which embed their $\mathrm{R} \& \mathrm{D}$ efforts in domestic networks. We report collaboration relationships with science partners in order to proxy the companies' utilization of the domestic knowledge_infrastructure. We also report the companies' embeddedness in vertical networks with suppliers and customers as well as their embeddedness in horizontal networks with competitors. We observe that the domestic multinationals are most embedded in the domestic networks. Foreign-owned companies, however, seem to be slightly more embedded in the domestic networks than their domestically owned uninational counterparts. 
Table 6: Embeddedness in national innovation systems. Fraction of firms.

\begin{tabular}{|l|ccc|ccc|ccc|}
\hline & \multicolumn{3}{|c|}{$\begin{array}{c}\text { Domestic } \\
\text { uninational }\end{array}$} & \multicolumn{3}{c|}{$\begin{array}{c}\text { Domestic } \\
\text { multinational }\end{array}$} & \multicolumn{3}{c|}{$\begin{array}{c}\text { Foreign } \\
\text { multinational }\end{array}$} \\
\hline & Sci & Ver & Hor & Sci & Ver & Hor & Sci & Ver & Hor \\
\hline Denmark & 15.7 & 24.7 & 6.4 & 50.6 & 70.2 & 12.8 & 16.0 & 24.0 & 3.2 \\
Finland & 41.9 & 46.5 & 11.9 & 95.7 & 91.4 & 34.4 & 49.6 & 53.8 & 9.2 \\
Norway & 18.3 & 27.2 & 4.7 & 65.4 & 65.4 & 7.3 & 22.2 & 28.1 & 5.5 \\
Sweden & 17.9 & 23.4 & 5.9 & 69.3 & 82.2 & 20.9 & 29.8 & 34.6 & 4.8 \\
\hline
\end{tabular}




\section{EMPIRICAL MODEL AND IMPLEMENTATION}

A common empirical approach for analyzing the relationship between $R \& D$, innovation and productivity is a parametric model of Cobb-Douglas form. Many recent versions of this standard model include techniques to correct for selection bias. When only the innovation sample is used in some parts of the model, the firms are not randomly drawn from the larger population, and selection bias may arise. The innovation literature (see, seminal papers by Pakes and Griliches 1984) has also suggested that, due to the complicated process from new ideas to innovation output or productivity growth, a knowledge production function should be estimated not as a single equation but as a system of equations. However, when several links of the process of transforming new ideas to productivity are considered in a simultaneous equation framework, one possible problem is that some explanatory variables are not exogenously given, and this leads to simultaneity bias. Crépon, Duguet and Mairesse (1998) launched an empirical model $(\mathrm{CDM})$, which both relates innovation input to innovation output accounts for both selectivity and simultaneity issues. The analysis in this paper applies the Lööf-Heshmati (2002) modification of the original CDM-model.

\subsection{Formulation of the model}

The general structure of the empirical model can be interpreted as a multi-step model consisting of four equations. At the first step, firms decide whether or not to engage in innovation activities (selection equation), and then a selective group of the firms decide how much they will invest in R\&D. This is specified by a Heckman selection model. The second part of the model can be formulated as an instrumental variable equation or a three-stage ordinary least square equation. We employ the instrumental variable equation, which relates innovation input to innovation output, and innovation output to productivity. More specifically, the model is given by the following four equations:

$$
\begin{aligned}
& y_{0 i}= \begin{cases}1 & \text { if } \quad y_{0 i}^{*}=X_{0 i} \beta_{0}+\varepsilon_{0 i}>0 \\
0 & \text { if } \quad y_{0 i}^{*}=X_{0 i} \beta_{0}+\varepsilon_{0 i} \leq 0\end{cases} \\
& y_{1 i}=y_{1 i}^{*}=X_{1 i} \beta_{1}+\varepsilon_{1 i} \text { if } y_{0 i}=1
\end{aligned}
$$




$$
\begin{aligned}
& y_{2 i}=\alpha_{21} y_{1 i}+\alpha_{23} y_{3 i}+X_{2 i} \beta_{2}+\varepsilon_{2 i} \text { if } y_{0 i}=1 \\
& y_{3 i}=\alpha_{32} y_{2 i}+X_{3 i} \beta_{3}+\varepsilon_{3 i} \text { if } y_{0 i}=1
\end{aligned}
$$

where $\mathrm{y}^{*}{ }_{0 \mathrm{i}}$ is a latent innovation decision variable measuring the propensity to innovate, $y_{0 i}$ is the corresponding observed binary variable being 1 for innovative firms. $y_{1 i}, y_{2 i}$ and $y_{3 i}$ describe innovation input, innovation output and productivity, respectively. $\mathrm{X}_{0 \mathrm{i}}, \mathrm{X}_{1 \mathrm{i}}$, $\mathrm{X}_{2 \mathrm{i}}$ and $\mathrm{X}_{3 \mathrm{i}}$ are vectors of various variables explaining innovation decision, innovation input, innovation output and labour productivity. The predicted inverse Mills' ratio (Heckman, 1979) is included in $\mathrm{X}_{2 \mathrm{i}}$ and $\mathrm{X}_{3 \mathrm{i}}$ to correct for possible selection bias. The $\beta$ 's and $\alpha$ s are the unknown parameter vectors. $\varepsilon_{0 \mathrm{i}}, \varepsilon_{2 \mathrm{i}}$ and $\varepsilon_{3 \mathrm{i}}$ are independent and identical distributed drawings from a multivariate normal distribution with zero mean. We start with the 5186 observations in equation (1), but the number of observations are restricted to the 2723 innovative firms (53\% of the observed firms) in equations 2-4.

\subsection{Specification of the model}

In equation (1), depicting the decision to be engaged in innovation activities, we first investigate the possible difference between domestically owned firms and foreign owned firms. The additional explanatory variables are firm size, human capital, merger and acquisition, labour productivity, gross investment, the firms' most important market and six dummy variables for sector classification: high technology manufacturing, medium high technology manufacturing, medium low technology manufacturing, low technology manufacturing, knowledge intensive and other services. The classification of industry sectors follows Hatzichronoglou (1997).

The innovation input equation (2) explores the importance of corporate ownership by comparing domestic uninationals, domestic multinationals, Nordic MNE, Anglo-Saxon MNE and MNEs from the rest of the world. In addition to sectors dummies, the following control variables are included: R\&D stock, public R\&D support, market orientation, innovation orientation (process or product) and firm size. 
Equation (3), reflecting innovation output, compares the five categories of ownership. Moreover, we include predicted labour productivity (from equation 4), and predicted innovation input (from equation 2), and the predicted inverted Mills' ratio (from equation 2) among the exogenous variables. The remaining 4 control variables are: firm size, public R\&D support, human capital and a composite variable aimed to capture the diversity of external collaboration on innovation. The six sector dummies are also included.

Equation (4), finally, investigates the relationship between labour productivity and the five categories of ownership. We also control for innovation output (that is, sales income from new products, predicted from equation 3), process innovation, gross investment, human capital, firm size and sector classification. To provide an overview, the endogenous and exogenous variables are defined in the Appendix, Table A and B.

\section{RESULTS}

The regression results for the selection model are presented in Table 7, while 8 provides the estimates from the two parts of the multistep model, i.e. the selection equation and the instrumental variable estimation.

\subsection{Innovative firms and R\&D intensity}


Table 7: Selection model

Panel 1: Dependent variable: Propensity to be engaged in innovation activities

\begin{tabular}{|c|c|c|c|c|c|c|c|c|}
\hline & \multicolumn{2}{|c|}{ Denmark } & \multicolumn{2}{|c|}{ Finland } & \multicolumn{2}{|c|}{ Norway } & \multicolumn{2}{|c|}{ Sweden } \\
\hline & Coeff & St.err. & Coeff & St.err. & Coeff & St.err. & Coeff & St.err. \\
\hline Domestically owned & Referenc & & Referenc & & Referenc & & Reference & \\
\hline Foreign-owned & -0.104 & 0.109 & -0.115 & 0.121 & $-0.283^{* * *}$ & 0.061 & 0.053 & 0.086 \\
\hline Firm size & $0.164^{* * *}$ & 0.367 & $0.223^{* * *}$ & 0.038 & $0.165^{* * *}$ & 0.024 & $0.198^{* * *}$ & 0.029 \\
\hline Human capital & $0.984^{* * *}$ & 0.269 & $0.361^{*}$ & 0.184 & $0.994^{* * * *}$ & 0.134 & $0.579^{* * *}$ & 0.204 \\
\hline M\&A & $0.462^{* * *}$ & 0.211 & -0.125 & 0.149 & $0.350^{* * *}$ & 0.082 & $0.216^{*}$ & 0.120 \\
\hline Labour product & $0.050^{* *}$ & 0.022 & $0.167^{* * *}$ & 0.060 & $0.059^{* *}$ & 0.025 & 0.078 & 0.051 \\
\hline Gross invest & 0.045 & 0.472 & $0.096^{* * *}$ & 0.039 & $0.130^{* * *}$ & 0.014 & 0.049 & 0.149 \\
\hline Local market & Referenc & & Referenc & & Referenc & & Reference & \\
\hline National market ${ }^{2}$ & 0.174 & 0.128 & $1.144^{* * * *}$ & 0.143 & $0.299^{* * * *}$ & 0.063 & $0.307^{* * *}$ & 0.108 \\
\hline Global market $^{2}$ & $0.274^{* *}$ & 0.141 & $0.789^{\text {*** }}$ & 0.162 & $0.503^{* * *}$ & 0.078 & $0.585^{* * *}$ & 0.118 \\
\hline Six sector dummies & Included & & Included & & Included & & Included & \\
\hline
\end{tabular}

Note: $* * *(* *, *)$ indicates significance at the $1 \%(5 \%, 10 \%)$,

Panel 1 of table 7 depicts the results from the estimated propensity to carry out innovations. This is also the first step in the selection equation. The most interesting finding is that no differences can be found between foreign-owned firms and domestically owned firms for three of the Nordic countries. Norway, however, deviates from the general Nordic pattern. For Norway, domestic firms have a significantly higher likelihood of being innovative than other firms.

Moreover, for the four different samples it is found that the likelihood of being an innovative firm is an increasing function of firm size, the fraction of employees with a university education and a global market orientation. With regard to labour productivity, gross investments and M\&A, the results are somewhat mixed. Productivity is significantly and positively associated with innovative firms in Denmark, Finland and Norway, but just outside the weakest acceptable level of significance in Sweden. The point estimate for gross investments is significant and positive in Finland and Norway, but not in Denmark and Sweden. The results on M\&A give some support for the hypothesis that innovative firms in Denmark, Norway and Sweden have a greater probability of being candiates for take-over. In Finland the relationship between M\&A and innovation is negative, but insignificant. 
Panel 2: Dependent variable: Log investments in R\&D and other innovation activities per employee

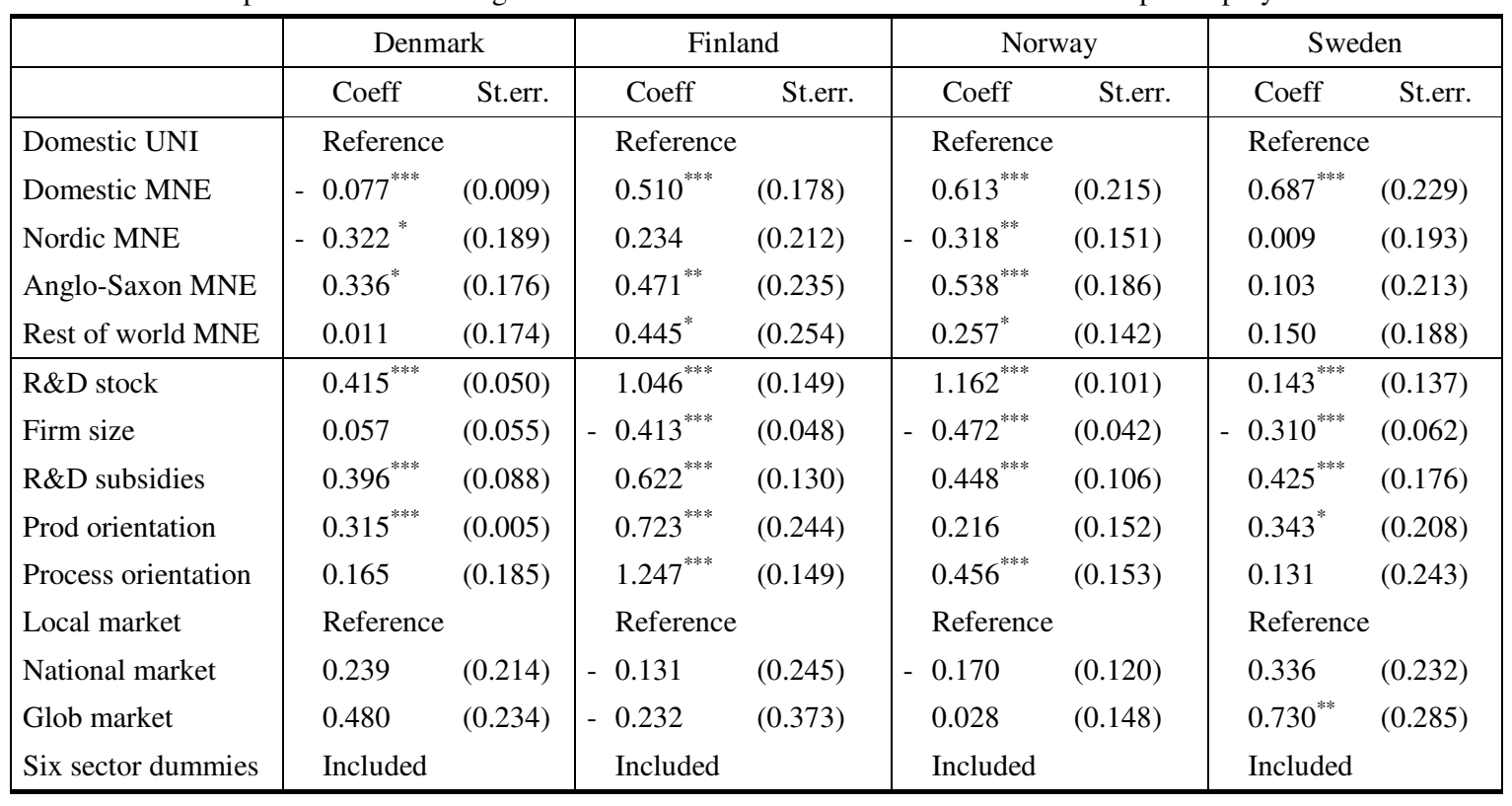

Note: $* * *(* *, *)$ indicates significance at the $1 \%(5 \%, 10 \%)$,

Panel 2 of Table 7 presents the determinants of the amount of R\&D and other innovation expenditures per employee. The evidence is compelling that domestic multinationals in Finland and Sweden outperform foreign-owned firms and uninational firms regarding R\&D investments, everything else being equal. In Norway domestic multinationals and Anglo-Saxon multinationals have significantly higher R\&D intensity than other firms. Notable is that Denmark deviates strongly, with a pattern where domestic multinationals have a significant lower R\&D intensity than uninational Danish firms.

It is shown that the $R \& D$-intensity is an increasing function of the stock of $R \& D$, proxied by whether or not the firm is conducting $R \& D$ on a continuous basis. Interestingly, we also see that the R\&D-intensity is closely associated with public R\&D subsidies. In all Nordic countries, except Denmark, the R\&D-intensity is a decreasing function of firm size. For other determinant variables, there is no common pattern of association with $\mathrm{R} \& \mathrm{D}$ among the different countries. 


\subsection{Innovation output and labour productivity}

The literature surveyed in Section 2, in combination with the descriptive statistics presented in Table 4, suggests that foreign firms tend to have higher levels of technology and productivity than domestically owned firms. One contribution of the present article is that we qualify the analysis somewhat by including corporate governance and differentiate between multinational firms and uninational firms as well as between categories of foreign-owned firms. Another distinctive feature of our analysis is that the regressions only consider innovative firms (although information from the total sample is used in the selection equation). A third aspect is that we only compare firms belonging to a group. Finally, we apply a multistep model, which captures not only one single relationship, but also the complete process from the decision to invest in $\mathrm{R} \& \mathrm{D}$ all the way to effects on labour productivity.

Table 8: Two stage least square model

Pane1 1: Dependent variable: Log innovation output (innovation sales) per employee.

\begin{tabular}{|c|c|c|c|c|c|c|c|c|}
\hline & \multicolumn{2}{|c|}{ Denmark } & \multicolumn{2}{|c|}{ Finland } & \multicolumn{2}{|c|}{ Norway } & \multicolumn{2}{|c|}{ Sweden } \\
\hline & Coeff & St.err. & Coeff & St.err. & Coeff & St.err. & Coeff & St.err. \\
\hline Domestic UNI & \multicolumn{2}{|c|}{ Reference } & \multicolumn{2}{|c|}{ Reference } & \multicolumn{2}{|l|}{ Reference } & \multicolumn{2}{|c|}{ Reference } \\
\hline Domestic MNE & 0.290 & 0.227 & $0.496^{* *}$ & 0.224 & -0.475 & 0.386 & $0.524^{*}$ & 0.268 \\
\hline Nordic MNE & 0.286 & 0.320 & 0.294 & 0.259 & 0.488 & 0.298 & $0.592^{* * *}$ & 0.209 \\
\hline Anglo-Saxon MNE & $0.673^{* *}$ & 0.342 & $0.545^{*}$ & 0.294 & - 0.478 & 0.351 & 0.362 & 0.257 \\
\hline Rest of world MNE & 0.192 & 0.252 & 0.238 & 0.310 & - 0.018 & 0.273 & 0.306 & 0.226 \\
\hline Labour productivity (pred) & $0.436^{* *}$ & 0.194 & 0.328 & 0.278 & -0.363 & 0.414 & $0.529^{*}$ & 0.293 \\
\hline Innovation input (pred) & 0.276 & 0.310 & 0.225 & 0.175 & $0.677^{* * *}$ & 0.138 & $0.331^{* * * *}$ & 0.122 \\
\hline Inverted Mills' ratio (pred) & - 0.707 & 1.393 & $-0.873^{*}$ & 0.742 & 0.996 & 0.702 & -0.894 & 0.799 \\
\hline Firm size & -0.034 & 0.126 & -0.153 & 0.111 & 0.027 & 0.108 & -0.093 & 0.113 \\
\hline Public funding for $R \& D$ & -0.222 & 0.217 & $-0.396^{*}$ & 0.230 & $-0.668^{* * *}$ & 0.222 & $0.545^{* * *}$ & 0.198 \\
\hline Collaboration diversity & 0.667 & 0.418 & $1.555^{* * *}$ & 0.349 & $2.398^{* * *}$ & 0.529 & $1.044^{* * *}$ & 0.385 \\
\hline Human capital & 0.485 & 0.536 & -0.553 & 0.371 & 0.704 & 0.501 & $0.830 *$ & 0.469 \\
\hline Six sector dummies & Included & & Included & & Included & & Included & \\
\hline
\end{tabular}

Note: $* * *(* *, *)$ indicates significance at the $1 \%(5 \%, 10 \%)$,

The results presented in Panel 1 of Table 8 show the elasticities of innovation output (innovation sales) with respect to corporate ownership. First, in Norway no difference between domestic and foreign firms can be established. In Denmark, it is only the estimated Anglo-Saxon innovation-sales parameter that is significantly larger than the 
parameter of other firms. With regard to Sweden, the estimate for domestic multinationals is positive and quite sizable (0.5), but significantly different from zero only at the $10 \%$ level. However, the elasticity of innovation sales, with respect to Nordic multinationals, is highly significant. The Finnish result reveals that the point estimate for Anglo-Saxon firms has a low level of significance. However, since the elasticity of innovation sales is significant for Finnish multinationals, we conclude that Finland is different from other Nordic countries regarding the direct economic impact of innovation; domestic multinationals outperform foreign-owned firms.

Pane1 2: Dependent variable: Log sales per employee (gross labour productivity)

\begin{tabular}{|c|c|c|c|c|c|c|c|c|}
\hline & \multicolumn{2}{|c|}{ Denmark } & \multicolumn{2}{|c|}{ Finland } & \multicolumn{2}{|c|}{ Norway } & \multicolumn{2}{|c|}{ Sweden } \\
\hline & Coeff & St. err & Coeff & St. err & Coeff & St. err & Coeff & St. err \\
\hline Domestic UNI & \multicolumn{2}{|l|}{ Reference } & \multicolumn{2}{|l|}{ Reference } & \multicolumn{2}{|c|}{ Reference } & \multicolumn{2}{|c|}{ Reference } \\
\hline Domestic MNE & -0.070 & 0.318 & -0.084 & 0.111 & -0.056 & 0.160 & -0.103 & 0.156 \\
\hline Nordic MNE & 0.484 & 0.302 & $0.174^{*}$ & 0.101 & $0.197^{* *}$ & 0.092 & 0.013 & 0.113 \\
\hline Anglo-Saxon MNE & 0.209 & 0.476 & 0.122 & 0.159 & 0.069 & 0.106 & 0.160 & 0.131 \\
\hline Rest of world MNE & 0.266 & 0.276 & 0.107 & 0.159 & 0.085 & 0.085 & -0.051 & 0.112 \\
\hline Innovation output (pred) & 0.404 & 0.385 & $0.202^{* *}$ & 0.086 & 0.064 & 0.051 & $0.221^{* * *}$ & 0.087 \\
\hline Gross invest per employee & $0.360^{* * * *}$ & 0.109 & $0.269^{* * *}$ & 0.038 & $0.208^{* * *}$ & 0.019 & $0.183^{* * *}$ & 0.050 \\
\hline Process innovation & -0.072 & 0.168 & -0.101 & 0.159 & -0.036 & 0.085 & -0.021 & 0.075 \\
\hline Size & $0.352^{* * *}$ & 0.117 & -0.009 & 0.070 & $0.043^{*}$ & 0.024 & 0.006 & 0.026 \\
\hline Human capital & $1.199^{*}$ & 0.626 & $0.639^{* * *}$ & 0.035 & 0.308 & 0.187 & -0.357 & 0.243 \\
\hline Six sector dummies & Included & & Included & & Included & & Included & \\
\hline
\end{tabular}

Note: $* * *(* *, *)$ indicates significance at the $1 \%(5 \%, 10 \%)$,

In Panel 2 of Table 8 the productivity estimates are presented. Considering first the estimates for Denmark and Sweden, it is apparent that there are no differences in labour productivity between foreign and domestic firms. Looking then at the Finnish sample, there is some evidence that Nordic firms have higher labour productivity than other firms. However, the estimate is significant only at the $10 \%$ level. The results for Norway show that the average Nordic multinational firm has a higher level of labour productivity than domestic multinationals and uninationals. But the sensitivity test also shows that no significant difference can be found between Norwegian firms, Anglo-Saxon firms and Continental European firms. 


\section{SUMMARY AND CONCLUDING REMARKS}

This paper has examined the innovation behaviour and productivity performance of foreign takeovers by comparing foreign-owned firms and domestically owned firms in the Nordic region. For companies that have been taken over, however, we cannot observe their behaviour and performance in the counterfactual state. In other words, we have no direct answer to the question: "What would the innovative activities have been, had the companies not been taken over?" In the study the domestically owned companies serve as a proxy for the companies in the state of no takeover. The paper also poses the following question: does it matter if a Nordic, Anglo-Saxon or any other MNE makes a take-over?

The descriptive statistics, which do not consider any firm-specific or industry-specific differences, show a robust pattern of superiority for foreign-owned firms across all four Nordic countries. The foreign-owned firms in the Nordic countries are distinguished by having a larger proportion of innovative firms, higher R\&D intensity, higher level of innovation sales per employee, higher levels of labour productivity and larger export intensity.

The econometric approach used intends to explore whether foreign-owned firms perform or behave differently than domestic firms ceteris paribus? If the ceteris paribus condition is satisfied, a reasonable conclusion is that a superior performance indicates possible welfare gains while inferior results in terms of innovation and productivity indicate the opposite.

In the econometric analysis we find that the propensity be engaged in $R \& D$ and innovation activities does not differ between foreign-owned firms and domestically owned firms in the Nordic region, with the exception of Norway. In Norway, the group of foreign firms have a significantly lower likelihood to be innovative than domestic firms. 
Among innovative firms though, the results regarding $R \& D$-intensity ( $R \& D$ per employee), are somewhat mixed across the countries. In Finland, Sweden and Norway, the R\&D-intensity of domestic multinationals is larger compared to all other corporate styles. However, the result is statistically significant only for Sweden. The deviating country in this respect is Denmark. The Danish multinationals have a lower R\&D intensity than both uninational firms and foreign-owned firms.

The evidence regarding embeddedness in the four countries' systems of innovation is presented in the descriptive statistics, and is quite evident. Domestic multinationals play a dominant role in the three sub-systems of innovation, scientific, vertical and horizontal. A priori, we therefore expect that technological spillovers through various systems of innovation would manifest itself in the innovation output performance. However, controlling for R\&D intensity (which is significantly lager for domestic MNEs), but not for embeddedness in the systems of innovation, we find do not any systematic difference between domestic and foreign firms for the four Nordic countries as a group. Actually, only in Finland do domestic multinationals have larger income than other firms from innovation sales. In Sweden, the regression results indicate that Nordic multinationals outperform other firms. For Norway, the analysis cannot establish any significant differences between domestic and foreign firms. The Danish results indicate that foreignowned companies are more innovative than domestic firms.

A possible interpretation of the seemingly paradoxical results regarding innovation output (innovation sales) is that multinational companies tend to utilize R\&D laboratories in the Nordic home countries for the development of assets which are exploited by affiliates abroad. Correspondingly, the innovation performance attributed to foreign-owned multinationals in the Nordic region partly represents returns to R\&D-investments in their home countries. It should be noted that we have found that both foreign-owned and domestically owned multinationals exploit knowledge for innovation from affiliates within their own group to a significantly larger extent than uninational companies do. 
The final and most important result of our study concerns productivity, which can be interpreted as a direct welfare indicator. Our main research issue was to investigate the welfare effect of foreign take-over of national assets. If foreign companies due to specific advantages such as greater production efficiency, grater efficiency in the R\&D-process, superior product design, more advanced product design and others, outperform domestic companies even when controlling for firm characteristics and industry classification, the dramatic increase in the foreign-ownership over the past decades in the Nordic countries would generate a welfare gain. Alternatively, if the foreign companies are underperformers relatively to domestic firms, the effect of foreign take-overs would be a welfare drain. The existing literature is mixed in this crucial issue. Our results support recent findings by Doms and Jensen (1998) and Pfaffermayr and Bellak (2002) showing the importance of a proper control for corporate ownership structure. To compare foreign-owned firms as a group with domestically firms as a group is to compare apples with oranges. A majority of the domestic firms are small independent firms, very different from foreign multinationals in several important ways. The relevant comparison should be between foreign and domestic firms belonging to a company group.

In this paper we separated the observed Nordic firms into five different groups: firms belonging to a group with only domestic affiliates (uninational firms), domestic multinationals, firms owned by some neighbouring Nordic country, Anglo-Saxon multinationals and foreign owned multinationals from Rest of the World. The result from the productivity regression shows no systematic difference between these five categories of firms.

The following tentative conclusions can be drawn from the study. Firstly, there are some significant differences between multinational and uninational firms. We find that both foreign-owned and domestically owned multinationals to a larger extent than uninational companies exploit knowledge for innovation from affiliates within their group. Hence, if the firms that have been taken-over are former uninational firms, we can expect increased global knowledge spillovers. Secondly, we believe that the R\&D-strategy of foreignowned firms has a significant influence on innovation behaviour. If the foreign direct 
investments are of the home-base-exploiting type, this can reduce the firms' incentive to sustain or increase the R\&D-intensity and to collaborate on innovation with various partners within the national innovation systems. However, a home-based-augmenting strategy can have the opposite effect. In this case, the intention is to acquire knowledge flows and technological spillovers from agglomerative effects in specific sectors, specific firms, and public infrastructure in the host country. Thus, take-overs can have two diametrically opposite motives, and this may help to explain why some of our empirical findings differ across the four host countries and across the home countries of foreignowned firms. 


\section{REFERENCES}

Aitken, B.J. and A.E. Harrison (1999), ”Do Domestic Firms Benefit from Direct Foreign Investment? Evidence from Venezuela", American Economic Review 89, 605-618.

Andersson, U. (1997) "Subsidiary network embeddedness: Integration, control and influence in the multinational corporation." Doctoral thesis, Department of Business Studies, Uppsala University, Sweden.

Audretsch, D. B, \& M. P. Feldman (1996), "R\&D Spillovers and the Geography of Innovation and Production", The American Economic Review, Vol. 86, No. 3: 630640.

Balcet, G. and R. Evangelista (2004), "Global Technology: Innovative Strategies of Multinational Affiliates in Italy”, Paper presented at the $10^{\text {th }}$ International Schumpeter Society Conference, Milan.

Barrios. S., H. Görg and E. Strobl (2004), "Foreign direct investment, competition and industrial development in host country", German Institute for Economic Research, DIW, Discussion Papers 426.

Cantwell, J. (1989), "Technological Innovation and Multinational Corporations," Blackwell (Basil), Oxford.

Cantwell, J., and O. Janne (1999), "Technological globalisation and innovative centres: the role of corporate technological leadership and location hierarchy," Research Policy 28 2-3, 119-144.

Conyon, M., S. Grima, S Thompson and P. Wright (1999), "Foreign Direct Investments, R\&D \& Spillover Efficiency: Evidence from Taiwan's Manufacturing Firms," Journal of Development Studies 22, 117-137.

Crépon, B., E. Duguet and J. Mairesse (1998), "Research, Innovation and Productivity: An Econometric Analysis at the Firm Level," Economics of Innovation and New Technology 7, 115-158.

Doms, M., E \& J. Bradford Jensen (1998) "Comparing Wages, Skills, \& Productivity between Domestically \& Foreign- Owned Manufacturing Establishments in the United States,” In R., E. Baldwin, R., E. Lipsey \& J., David Richardson (Eds) 
Geography \& Ownership as Bases for Economic Accounting, Studies in Income \& Wealth, 59, Chicago, University of Chicago Press, 235-258.

Dosi, G. (1988), "The nature of the innovation process," In Dosi, G., et al (Eds.), Technical Change and Economic Theory. Frances Piter Publishers, London.

Ebersberger, B. and H.Lööf (2005), Corporate innovation activities, does ownership matter? The CIS Study Statistical Report. Nordic Innovation Centre's Forum for Innovation Policies.

Findlay, R. (1978), "Relative backwardness, direct foreign investment and the transfer of technology: a simple dynamic model”, Quarterly Journal of Economics, 92, 1-16.

Feliciano, Z., and R.E. Lipsey (2002), "Foreign entry into US. manufacturing by takeovers and the creation of new firms", NBER Working Paper no 9122.

Frenz, M., and G.Ietto-Gillies (2004), “The impact of multinationality on the propensity to innovate: An analysis of the UK Community Innovation Survey 3", paper presented at the 2004 Schumpeter conference in Milan.

Furu, P. (2001), "Drivers of competence development in different types of multinational subsidiaries", Scandinavian Journal of Management 17, 133-149.

Globerman, S.,J. Ries and I. Vertinsky (1994), "The economic performance of foreign affiliates in Canada," Canadian Journal of economics 27 1, 143-156.

Grossman, G. M., E, Helpman.and A. Szeidl (2006), “Optimal Integration Strategies for the Multinational Firm", Journal of International Economics, forthcoming.

Harris, R. and Robinson, C. (2002), “The Effect of Foreign Acquisitions on Total Factor Productivity: Plant Level Evidence from UK Manufacturing, 1987-1992, Review of Economic Statistics 48 3, 562-568.

Hatzichronoglou, T. (1997), "Revision of the High-Technology Sector and Product Classification," Vol. 2 of STI Working Papers, OECD, Paris.

Heckman, J.J. (1979), "Sample Selection Bias as a Specification Error," Econometrica 47, 153-162.

Helpman, E., M.J. Melitz and S.R. Yeape (2003), "Export versus FDI with Heterogeneous Firms," American Economic Review. 
Jaffe, A., M Trajtenberg and R.Henderson (1993), Geographical localization of knowledge spillovers as evidence by patent ciations," Quarterly Journal of Economics 198, 577-599.

Kleinknecht, A., K van Montfort and E. Brouwer (2002), "The non-trivial choice between innovation indicators." Economics of Innovation and New Technology 11, $109-121$

Klevorick, A. K., R. C. Levin, R.R. Nelson and S.Winter (1995), "On the sources and significance of interindustry differences in technological opportunities," Research Policy 24, 185-205.

Kuemmerle, W (1999), "Foreign direct investment in industrial research in the pharmaceutical and electronic industries - results from a survey of multinational firms," Research Policy 28 2-3, 179-193.

Lall, S. (1979), "The International Allocation of Research Activity by U.S. Multinationals," Oxford Bullentin of Economic Statistics, 41 313-331.

Lipsey, R.E. (2002), “Home and Host Country Effects of FDI,” NBER Working Paper No 9293.

Lööf, H. and A. Heshmati (2002), “Knowledge Capital and Performance Heterogeneity: A Firm Level Innovation Study," International Journal of Production Economics $76(1), 61-85$.

Lundberg , L \& P. Karpaty, P (2004), "Foreign Direct Investment \& Productivity Spillovers in Swedish Manufacturing," FIEF Working Paper Series No. 194

Lundvall, B-Å. (Ed.) (1992), "National System of Innovation: Towards a Theory of Innovation and Interactive Learning," Printer, London.

Nelson, R. (Ed.), (1992), "National Innovation Systems: a Comparative Analysis," Oxford Univ. Press.

Pakes, A. and Z. Griliches (1984), "Patents and R\&D at the Firm Level: A First Look," in: Griliches, Z. (ed.), R\&D, Patents, and Productivity, Chicago, 55-71.

Patel, P. (1995), "Localised production of technology for global markets", Cambridge Journal of Economics 19 (1), 141-154. 
Pavitt, K., M. Robson and J. Townsend (1987), "The Size Distribution of Innovating Firms in the UK: 1945-1883." The Journal of Industrial Economics 35, 297-316.

Pavitt, K. and P. Patel (1999), "Global corporations and national systems of innovation who dominates whom?” In: D. Achibugi, J. Howells and J. Michie (eds.), Innovation Policy in a Global Economy, Cambridge: Cambridge University Press, pp 94-119.

Pfaffermayr, M and C. Bellak (2002), Why Foreign-owned Firms are Different: A Conceptual Framweork and Empirical Evidence for Austria. In R. Jungnickel (ed.) Foreign-owned Firms, Are They Different? Palgrave Macmillan, 13-57

Porter, M (1990), “The Competitive Advantage of Nations", London, Mcmillan. 


\section{APPENDIX: Definition of the variables}

Table A: The dependent variables in equations 1-4.

\begin{tabular}{|l|l|}
\hline Endogenous variables & Definition \\
\hline Innovative firm & $\begin{array}{l}\text { Innovative firms are firms reporting a product and/or process } \\
\text { innovation and/or report ongoing innovation activities. } \\
\text { The firm's expenditures on R\&D and other innovation activities per } \\
\text { employee (log). } \\
\text { The return on innovation investments. Innovation sales per employee } \\
\text { Innovation sales/Innovation output }\end{array}$ \\
Labour productivity & $\begin{array}{l}\text { log). } \\
\text { Sales per employee }(\log ) .\end{array}$ \\
\hline
\end{tabular}


Table B: The independent variables in the equations 1-4

\begin{tabular}{|c|c|}
\hline Exogenous variables & Definition \\
\hline Domestically owed firm & Firms with headquarter in Sweden \\
\hline Foreign-owned firm & $\begin{array}{l}\text { Firms with headquarters in a foreign country are used as a proxy for } \\
\text { foreign-owned firms }\end{array}$ \\
\hline Uninational Enterprises & $\begin{array}{l}\text { Domestically-owned firms belonging to a group with only domestic } \\
\text { affiliates }\end{array}$ \\
\hline $\begin{array}{l}\text { Domestically-owned multinational } \\
\text { enterprises }\end{array}$ & Domestically-owned firms belonging to a group with foreign affiliates \\
\hline Nordic-owned multinational enterprises & $\begin{array}{l}\text { Multinational firm with the headquarters in some of the Nordic } \\
\text { neighbouring countries }\end{array}$ \\
\hline $\begin{array}{l}\text { Anglo-Saxon owned multinational } \\
\text { enterprises }\end{array}$ & $\begin{array}{l}\text { Multinational firm with the headquarters in USA, United Kingdom, } \\
\text { Ireland, Canada or South Africa }\end{array}$ \\
\hline $\begin{array}{l}\text { Rest of the world multinational } \\
\text { enterprises }\end{array}$ & $\begin{array}{l}\text { Multinational firm with the headquarter in continental European } \\
\text { countries or other countries }\end{array}$ \\
\hline Product oriented innovation strategy & $\begin{array}{l}\text { Composite variable composed by variables "Increased range of goods } \\
\text { or services", "Increased market or market share" and "Improved } \\
\text { quality in goods or services" as expected effects of innovation }\end{array}$ \\
\hline Process oriented innovation strategy & $\begin{array}{l}\text { Composite variable composed of variables "Improved production } \\
\text { flexibility", "Increased production capacity" and "Reduced labour } \\
\text { costs per produced unit" as expected effects of innovation }\end{array}$ \\
\hline Continuous R\&D & Continuously R\&D engagement \\
\hline Diversity & Domestic and global cooperation on innovation \\
\hline Firm size & Employment (log). \\
\hline Human capital & $\begin{array}{l}\text { The fraction of employment with a university education is used as a } \\
\text { proxy for human capital }\end{array}$ \\
\hline $\begin{array}{l}\text { Recent history of merging and } \\
\text { acquisition }\end{array}$ & The enterprise has been merged or acquired during the last three years \\
\hline Productivity & $\begin{array}{l}\text { Sales per employee }(\log ) \text {. Indicates financial means for R\&D } \\
\text { investments. }\end{array}$ \\
\hline Gross investment & Gross investment per employee $(\log )$ \\
\hline Significant market area - local & The firms' most significant market \\
\hline Significant market area - national & The firms' most significant market \\
\hline Significant market area - global & The firms' most significant market \\
\hline High technology manufacturing sector & Nace 353 , Nace 2423, Nace, 30, Nace 32, Nace 33 \\
\hline $\begin{array}{l}\text { Medium high technology manufacturing } \\
\text { sectors }\end{array}$ & $\begin{array}{l}\text { Nace } 24 \text { excl Nace 2423, Nace 29, Nace 31, Nace 34, Nace 352, Nace } \\
359\end{array}$ \\
\hline $\begin{array}{l}\text { Medium low technology manufacturing } \\
\text { sectors }\end{array}$ & Nace 23, Nace 25, Nace 26, Nace 37, Nace 28, Nace 351, Nace 354 \\
\hline Low technology manufacturing sectors & $\begin{array}{l}\text { Nace } 15, \text { Nace } 16 \text {, Nace } 17 \text {, Nace } 18 \text {, Nace } 19 \text {, Nace } 20 \text {, Nace } 21 \text {, } \\
\text { Nace } 36 \text {, Nace } 37\end{array}$ \\
\hline Knowledge intensive services & $\begin{array}{l}\text { Nace } 64, \text { Nace } 65 \text {, Nace 66, Nace 67, Nace 71, Nace 72, Nace } 73 \text {, } \\
\text { Nace } 74\end{array}$ \\
\hline Other services & Services other than Knowledge intensive services \\
\hline
\end{tabular}

